\title{
15. A SYNTHESIS OF THE MAGMATIC EVOLUTION OF THE BRITO-ARCTIC PROVINCE, INCLUDING DATA FROM DSDP LEG 38
}

\author{
W.I. Ridley, Lamont-Doherty Geological Observatory, Columbia University, Palisades, New York
}

\section{INTRODUCTION}

The Brito-Arctic Province is an extensive region of Tertiary to Recent volcanic activity. The NorwayGreenland Sea area forms part of this province. Also included within its boundaries are the volcanics of East and West Greenland, West Soctland and Northeast Ireland, Iceland, Jan Mayen, and the Faeroes. Volcanic activity is manifest in all these areas by vast fissure-type outpourings of basaltic lava associated with very minor amounts of more silicic magma. The prior existence of large central-type volcanoes built upon the lava plateau is reflected in the spectacular intrusive centers in Ireland (Mourne Mountains, Carlingford, Slieve Gullion); Scotland (Skye, Rhum, Mull, Ardnamurchan, Arran); and East Greenland (Skaergaard, Kangerdlugssuaq, Cap Edvard Holm, Kaerven). Several of these complexes have been discussed in detail by Wager and Brown (1967). Most attention has been paid to the central complexes because of their spectacular rock types, whereas relatively little detailed petrochemistry is available for the much more voluminous basalts.

\section{MAGMATIC ACTIVITY}

Magmatic activity began in the Paleocene or lower Eocene, although no radiometric ages are available. Oceanic crust had developed by $58 \mathrm{~m} . \mathrm{y}$. if the recognition of anomaly 23 is correct. Large volumes of basalt had already been erupted onto fractured continental crust prior to this time. The remnants of this initial activity include: (1) The Antrim Plateau basalts, Ireland, approximately $10^{4} \mathrm{~km}^{3}$ erupted onto Cretaceous and lower Paleozoic basement, (2) The West Scotland Plateau basalts, approximately $2 \times 10^{3} \mathrm{~km}^{3}$, and (3) The basalt plateau of East Greenland. The largest of these, the Southern Plateau basalts have an estimated volume of $5 \times 10^{6} \mathrm{~km}^{3}$ and erupted onto Cretaceous and lower Eocene sediments. The lava plateau of the fossil Faeroe Islands was probably built at about this time, since the basalts have crystallization ages between 50-60 m.y.B.P. (Tarling and Gale, 1968). In most of these regions, early, detailed mapping indicated that the fissure basalts erupted onto an erosional land surface with roughly synchronous tilting, flexuring, and vertical displacement of large continental blocks (Koch, 1929; Vischer, 1943; Wager, 1947; Tomkieff, 1964; Harker, 1904). These epeirogenic movements we now equate with the Paleocene-Eocene fragmentation of Greenland from northern Europe.

Even at this stage of incipient opening a variety of basalt magmas were erupted at the surface. The plateau basalts in West Scotland are mildly alkalic olivine tholeiites and alkali olivine basalts (Thompson et al., 1972; Ridley, 1971). Those on Skye (and by inference, the whole British Tertiary subprovince) were erupted prior to $54 \pm 3$ m.y.B.P. (Moorbath and Bell, 1965). However, it should be noted that, at least on Skye, the mildly alkalic plateau basalts are underlain by a few flows of tholeiitic pillow lavas (Anderson and Dunham, 1966) and interbedded near the top of the plateau with flows of low-alkali tholeiite (Thompson et al., 1972), similar in composition to modern abyssal tholeiites. The further availability of tholeiitic magmas at approximately $55 \mathrm{~m} . \mathrm{y}$. is indicated by the intrusive centers (Wager and Brown, 1967), although these magmas may have been eucritic (Donaldson, 1974). The Antrim Plateau basalts are chemically different in that they are largely composed of potash-rich quartz tholeiites.

The plateau lavas that erupted at the ancestral site of the Faeroe Islands in East Greenland are composed of two lower units of quartz tholeiites (which are chemically distinct from the Antrim lavas) and an upper group of olivine tholeiites (Noe-Nygaard and Rasmussen, 1968). The lower groups are chemically undistinguishable from quartz tholeiites erupted at Scoresby Sund, East Greenland (Schilling and NoeNygaard, 1974). This extensive plateau must have been built synchronous with the British Tertiary Plateau and involved a rather bewildering variety of basalt magmas.

Detailed studies on selected areas within this early region of basalt magmatism have led to some conclusions regarding magma petrogenesis. In light of the above review, these petrogenetic deductions cannot be extended to the entire province, without complexion. Detailed studies of British Tertiary plateau basalts have been carried out by Ridley (1971) and Thompson et al. (1972). The latter authors suggest that the progression from alkalic basalts and olivine tholeiites to low-alkali tholeiites was produced along an increasing temperature gradient during a major mantle thermal event. Presumably this event was closely related to the initial rifting. Detailed isotopic and trace element analyses have not been reported; available geochemical data are equivocal as to the chemical variability of the mantle source region for these basalts.

Schilling and Noe-Nygaard (1974) have carried out a detailed geochemical study of Faeroe Islands basalts, concluding that the quartz-tholeiites are derived from deeper sources (mantle-plume derived magmas) than the olivine tholeiites, which may be derived from the low-velocity zone. Both this and the previous model have in common the necessity for major mantle thermal perturbations, although in detail the models are different. The apparent differences in chemistry suggest that at present neither model is strictly applicable to the other area.

The evolution of the Brito-Arctic Province after about 50 m.y.B.P. essentially involved creation of new oceanic crust as Greenland and northern Europe 
parted. However the detailed evolution is complex involving the development and abandonment of centers of spreading, changes in spreading direction, development of major fracture zones and culminating with the development of Iceland and the modern Reykjanes and Kilbeinsey ridges. These kinetic changes may partly reflect thermal changes within the mantle, or may in turn have instigated thermal responses within the mantle. Hence, we might expect that no simple pattern of magmatic activity would emerge from such a structurally complex region. In addition, we should be aware that even with the data available from Leg 38 there still remains vast unsampled regions of the sea floor. Regional extrapolations should thus be cautiously applied.

The basalts erupted on the $\mathrm{V} \phi$ ring Plateau represent basement formed perhaps 5-10 m.y. after continental parting (M. Talwani, personal communication). They include both quartz and olivine-tholeiites that have closest chemical affinities to the Faeroe plateau basalts, but are unlike the basalts from the British Tertiary Province. If basalt from Site 345 were included, and assigned an upper Eocene age, then the majority of the sites $(345,342,343)$ are within "plume-derived" basement which may reflect up to 10 m.y. of magma generation from sources deeper than the low-velocity zone. We are aware, however, that since Site 345 is within a structurally complex area, the basement basalts may be genetically related to the Jan Mayen Fracture Zone (Raschka et al., this volume). If so, then basement at Sites 338, 342, and 343 may reflect quite rapid fluctuations between eruptions of "plume-derived" and "low-velocity zone-derived" magmas.

With the isolation of the Faeroe Plateau as a continental fragment, sea-floor spreading continued west of the Faeroe Islands with eruption of abyssal thoeliites essentially similar to those represented by the upper olivine tholeiite group on the Faeroes. This seems to have been the dominant basalt erupted until at least 19 m.y.B.P. (Kharin et al., this volume) and presumably forms most of the post-Eocene oceanic crust in this region.

At approximately $20 \mathrm{~m} . y$. B.P., Iceland began to develop as an anomalous region in which the rate of magma production exceeded that along the adjoining segments of the Reykjanes and Kolbeinsey ridges. Between this time and about 3 m.y.B.P. a 10-km-thick pile of basalts was built, represented today by the basalt plateau of East and West Iceland. Detailed petrologic studies are not abundant compared to studies of postglacial basalts. To the extent that generalities can be made, the Tertiary volcanics comprise quartz tholeiites and lesser amounts of olivine tholeiites, characterized by enrichment in $\mathrm{FeO}$ and $\mathrm{TiO}_{2}$ compared to "normal" abyssal tholeiites. Similar tholeiitic basalts have been erupted from the western and eastern axial zones up to the present time, excepting a distinctive group of alkalic basalts associated with the Snafellsnes Fracture Zone (Jakobsson, 1972, Sigvaldason, 1969, Sigurdsson, 1970). Hence the growth of Iceland represents not only a volume anomaly, but also a chemical anomaly instigated about 20 m.y.B.P.
Systematic changes in trace element chemistry and isotopic composition of basalts erupted along the Reykjanes Ridge as it approaches Iceland led Schilling (1973) to postulate that Iceland lay above a deep mantle magma source ("plume"). The geochemical changes were explained as mixing of this magma with typical "depleted" olivine tholeite magma generated within the low-velocity zone. Although still applicable, this simple mixing model requires modificaton in light of detailed isotopic analysis of Quaternary to Recent basalts from Iceland (O'Nions and Pankhurst, 1974). These data indicated a sharp, rather than gradual, change in magma type at the Tjornes Fracture Zone north of Iceland and the coeval eruption of abyssal tholeiites and more radiogenic basalts within the eastern volcanic zone of Iceland.

\section{SUMMARY}

Summarily, the large volume and continuity of basalt eruptions in the Brito-Arctic Province indicate this region has been thermally anomalous for at least 60 m.y. During this time the thermal regimes within the mantle must have been quite variable, since we observe a wide spectrum of basaltic rocks at the surface. Some of these regimes may have developed in response to the rearrangement of lithopheric plates, for instance, fracture zones may have distinctive magmatic activity associated with them. In such a situation, we might expect to have developed variable magma types depending upon the complexity of the structural setting. In addition, a more fundamental, regional thermal perturbation may have instigated lithospheric plate motion, and we might expect to find a temporally more uniform magma type associated with such a perturbation. None is immediately identifiable. If the thermal perturbations resulted in mantle diapirism, which in turn fed magma to the surface, then the observed magma variability would be more consistent with the sporadic development of mantle "blobs" (in the usage of Schilling) rather than steady mantle "plumes." Within a framework of a regional, steadily rising, geothermal gradient which caused lithospheric tumescence and fragmentation, more localized mantle diapirs developed, e.g., beneath West Scotland, Ireland, and Faeroes. Each diapir may have produced a magma of slightly different composition depending upon the local regime of pressure, temperature, and mantle composition. Other diapirs may have arisen during the development of the V $\phi$ ring Plateau and Iceland.

\section{REFERENCES}

Anderson, F.W. and Dunham, K.C., 1966. The geology of Northern Skye: Mem. Geol. Surv. Gt. Britain.

Donaldson, C.H., 1974. Olivine crystal types in harristic rocks of the Rhum pluton and in Archean spinifex rocks: Geol. Soc. Am. Bull., v. 85, p. 1721-1726.

Harker, A., 1904. The Tertiary igneous rocks of Skye: Mem. Geol. Surv. Scotland.

Jakobsson, S.P., 1972. Chemistry and distribution pattern of Recent basaltic rocks in Iceland: Lithos, v. 5, p. 365-386. 
Koch, L. 1929. The geology of East Greenland: Amer. J. Sci., v. 209 , p. $271-285$.

Moorbath, S. and Bell, J.D., 1965. Strontium isotope abundance studies and rubidium-strontium determinations on Tertiary igneous rocks from the Isle of Skye, north-west Scotland: J. Petrol., v. 6, p. 37-66.

Noe-Nygaard, A. and Rasmussen, J., 1968. Petrology of a 3000 meter sequence of basaltic rocks in the Faeroe Islands: Lithos, v. 1, p. 286-304.

O'Nions, R.K. and Pankhurst, R.J., 1974. Petrogenetic significance of Isotope and trace element variations in volcanic rocks from the Mid-Atlantic: J. Petrol., v. 15, p. 603-634.

, in press. Sr. Isotope and rare-earth element geochemistry of DSDP Leg 37 basalts: Earth Planet. Sci. Lett.

Ridley, W.I., 1971. The petrology of some volcanic rocks from the British Tertiary Province: the islands of Rhum, Eigg, Canna and Muck: Contrib. Mineral. Petrol., v. 32, p. $251-266$.

Schilling, J-G., 1973. Iceland mantle plume: Nature, v. 246, p. 141 .

Schilling, J-G. and Noe-Nygaard, A., 1974. Faeroe-Iceland Plume: Rare-earth evidence: Earth Planet. Sci. Lett., v. 24, p. $1-14$

Sigurdsson, H., 1970. Structural origin and plate tectonics of the Snaefellsnes volcanic zone, Western Iceland: Earth Planet. Sci. Lett., v. 10, p. 129-135.

Sigvaldason, G.E., 1969. Chemistry of basalts from the Icelandic Rift Zone: Contrib. Mineral. Petrol., v. 20, p. $357-370$.

Tarling, D.H. and Gale, N.H., 1968. Isotopic dating and paleomagnetic polarity in the Faeroe Islands: Nature, v. 218, p. 1043.

Thompson, R.N., Esson, J., and Dunham, A.C., 1972. Major element chemical variation in the Eocene lavas of the Isle of Skye, Scotland: J. Petrol., v. 13, p. 219-253.

Tomkieff, S.I., 1964. Petrochemistry and petrogenesis of the British Tertiary Igneous Province: Adv. Frontiers Geol. Geophys., p. 327-350.

Vischer, A., 1943. Die postdevonische Tektonik von Ostgronland zwischen $74^{\circ}$ and $75^{\circ} \mathrm{N} \mathrm{Br}$. Kuhn $\mathrm{O}$, Wollaston Forland, Claver mg) und angrenzende: Gebiete. Medd. Gronland., v. 133, p. 1-195.

Wager, L.R., 1947. Geological investigations in East Greenland, Pt IV. The stratigraphy and tectonics of Knud Rasmussens Land and the Kangerdlugssuag region: Medd. Greenland, v. 134, p. 1-64.

Wager, L.R. and Brown, G.M., 1967. Layered igneous rocks: San Francisco. (W.H. Freeman and Co.).

APPENDIX

Precise $\mathrm{Sr}$ Isotope Determinations for Leg 38 Basalts

J. Hamilton, R.K. O'Nions, and N. Evensen, Lamont-Doherty Geological Observatory, Columbia University,

Palisades, New York

${ }^{87} \mathrm{Sr} /{ }^{86} \mathrm{Sr}$ ratios determined for these rocks are given in Table 1. They range from $0.70343 \pm 5$ to $0.70439 \pm 4$ and show no correlation with apparent freshness in thin section, age, or any available geochemical parameter. Much of the variation occurs over small distances, both laterally and vertically, and is considerably greater than would be expected for cogenetic basalts. Similar variation of ${ }^{87} \mathrm{Sr} /{ }^{80} \mathrm{Sr}$ ( 0.70297 to 0.70443 ) has been found for DSDP Leg 37 basalts (O'Nions and Pankhurst, in press), and was attributed to variable contamination with seawater strontium. It seems likely that much of the variation reported here may be attributed to the same cause.

Leaching of the samples with $6 M$ hydrochloric acid to remove the contaminant strontium (see O'Nions and Pankhurst, in press) will be undertaken to determine whether any of the variation is primary.

TABLE 1

Strontium Isotopic Compositions of Leg 38 Basalts

\begin{tabular}{lll}
\hline $\begin{array}{c}\text { Sample } \\
\text { (Interval in cm) }\end{array}$ & ${ }^{87} \mathrm{Sr} / 86 \mathrm{Sr} \pm 20$ & $\mathrm{Rb} / \mathrm{Sr}$ \\
\hline $336-41-1$, & $0.70355 \pm 5$ & 0.018 \\
$336-42-1,144-146$ & $0.70359 \pm 4$ & 0.006 \\
$337-13-2,140-145$ & $0.70398 \pm 6$ & 0.054 \\
$337-15-2,137-140$ & $0.70363+4$ & 0.043 \\
$338-43-2,115-118$ & $0.70419 \pm 4$ & 0.020 \\
$338-43-4,54-57$ & $0.70404 \pm 5$ & 0.023 \\
$338-45-2,56-59$ & $0.70352 \pm 4$ & 0.010 \\
$342-7-2,137-140$ & $0.70354 \pm 5$ & 0.028 \\
$342-7-5,126-129$ & $0.70374 \pm 6$ & 0.032 \\
$342-8-2,65-68$ & $0.70379 \pm 4$ & 0.016 \\
$343-13-2,20-23$ & $0.70370 \pm 4$ & 0.025 \\
$334-34-2,27-30$ & $0.70388 \pm 4$ & 0.065 \\
$334-35-4,87-90$ & $0.70376 \pm 4$ & 0.174 \\
$334-37-2,135-137$ & $0.70351 \pm 4$ & 0.046 \\
$345-33-2,56-59$ & $0.70343 \pm 5$ & 0.060 \\
$345-35-1,145-148$ & $0.70424 \pm 6$ & 0.082 \\
$348-32-4,93-96$ & $0.70439 \pm 4$ & 0.016 \\
$348-34-2,107-110$ & $0.70380 \pm 4$ & 0.014 \\
$350-16-2,30-33$ & $0.70400 \pm 4$ & 0.015 \\
\hline Note: (1) Measured ratios normalized to Sr 86 / \\
Sr88 = 0.1194, but not to a nominal stron- \\
tium standard determined on this machine. \\
(2) Samples 345-33-2, 56-59 cm and 345- \\
35-1, 145-148 cm have been corrected for \\
growth of radiogenic strontium since cor- \\
rection greater than 2 $\sigma$.
\end{tabular}

